\title{
Augmented Reality in Turkey with Researchers' Comments for Educational Use: Problems, Solutions and Suggestions
}

\author{
Özcan Erkan Akgün ${ }^{1}$, Aslıhan İstanbullu², Şirin Küçük Avci ${ }^{3}$ \\ ${ }^{1}$ Faculty of Educational Science, İstanbul Medeniyet University, İstanbul, Turkey \\ ${ }^{2}$ Vocational School of Technical Science, Amasya University, Amasya, Turkey \\ ${ }^{3}$ Faculty of Educational Science, Necmettin Erbakan University, Konya, Turkey \\ Correspondence: Özcan Erkan Akgün, Faculty of Educational Science, İstanbul Medeniyet University, İstanbul, Turkey.
}

Received: October 9, 2017

doi:10.11114/jets.v5i11.2690
Accepted: October 30, $2017 \quad$ Online Published: October 30, 2017

URL: https://doi.org/10.11114/jets.v5i11.2690

\begin{abstract}
Augmented reality (AR) is a technology to supplement existing reality with additional information, descriptions and helpful images with the help of technology and therefore ensure the reality to be perceived more qualified and well-rounded. In this study, views and comments about problems, solutions and suggestions on using AR were gathered from researchers who accomplished an applied study on AR. The phenomenological design, in qualitative framework, was used in the study. The purpose of the study is to investigate direct experiencers views on AR technologies. We tried to find out answer the following questions about augmented reality applications: "On which target group could it be used more effectively?", "On which learning domain (cognitive, affective, psychomotor) could it be more influential?", "Which teaching and learning methods could it be used with?", "What are the problems encountered during design, development and application process?", "What are the subject fields that need to be considered for using it more effectively in educational sciences field?", "In which situations could it be used for education?", and "How should it be designed?". According to the results, suggestions are presented about technical concerns, learning materials and instructional methods for developers, educators, and feature researchers for using AR effectively in education.
\end{abstract}

Keywords: augmented reality, education, teaching, learning, problems, solutions, suggestions

\section{Introduction}

Especially in the age we are living in, the new and emerging technologies became strong enough to affect social and economic conditions in the world (Arslan, 2003). Technology enables us to make our lives more efficient, fruitful, comfortable and productive. It also gives us opportunities to provide more qualified education. Researches show that education supported with proper technology gives more successful results (Akgün et al. 2014; Robertson, 2008; Resta \& Laferrière, 2007). When we use technologies in education, it can be named as educational technologies (Hefzallah, 2004).

Main purpose for using educational technologies is not only to distribute technological devices to students or place them on classes but to improve educational quality, to enable education efficient, fruitful, and attractive for the learner. Fulfilling this object requires educators to combine technology with their own study fields (Akkoyunlu, 2002). Therefore, this requirement leads educators to rethink their basic principles and reschedule these new technologies with reproductive methods (Kellner, 2002). Augmented reality is one of these new technologies to be used for education.Augmented reality (AR) is to supplement existing reality with additional information, descriptions and helpful images with the help of technology and therefore ensure the reality to be perceived more qualified and well-rounded. Although AR is considered within the same category as virtual reality (Bound, Haniff, Beber and Steiner, 1999), it has some differences that bring together virtual reality and real environment (Azuma, 1997). 


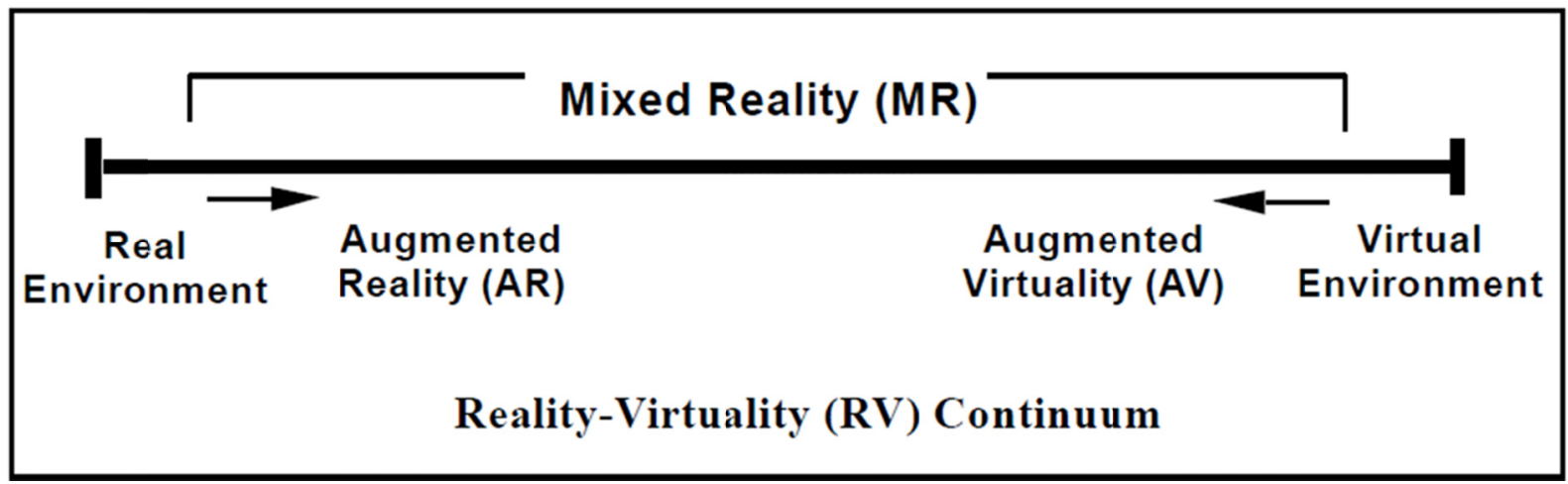

Figure 1. Reality-virtuality continuum (Milgram, Takemura, Utsumi \& Kishino, 1994, p.283)

With their "Reality-Virtuality Continuum", Milgram, Takemura, Utsumi and Kishino (1994) aim to clarify concepts between virtual and real environment (see Figure 1). In Figure 1, as in "Real Environment" part, there is the real world, what we see by naked eye without using any hardware. In "Virtual Environment" part there is the virtual realities with fictional world. The middle part between real and virtual parts is defined as "Mixed Reality" in which elements of real and virtual environment presented together (Milgram, 1994). Augmentation in the real environment is "Augmented Reality", augmentation in virtual environment is "Augmented Virtuality". As it moves left to right of the continuum, virtual image amount increases and linkage with the reality weakens. Briefly, augmented reality is to try to enrich a person's reality perception with the use of technology (Graham, Zook, \& Boulton, 2013).

AR is constituted as concurrent superimposition of computer generated digital data such as video, 3D, text, graphic etc. on real environment by using technological devices and applications. However an application has to have some features in order to be called as AR. According to Azuma's (1997) study, if an environment or application has a feature of;

- Virtual and real objects combine in real environment,

- The objects are aligned in a three-dimensional environment,

- Virtual and real objects have real-time interaction, this environment or application would be accepted as AR.

AR has a wide area of usage ranging from military to advertisement and is divided into two categories as image based, and location based according to the technology used (See Figure 2, Figure 3).

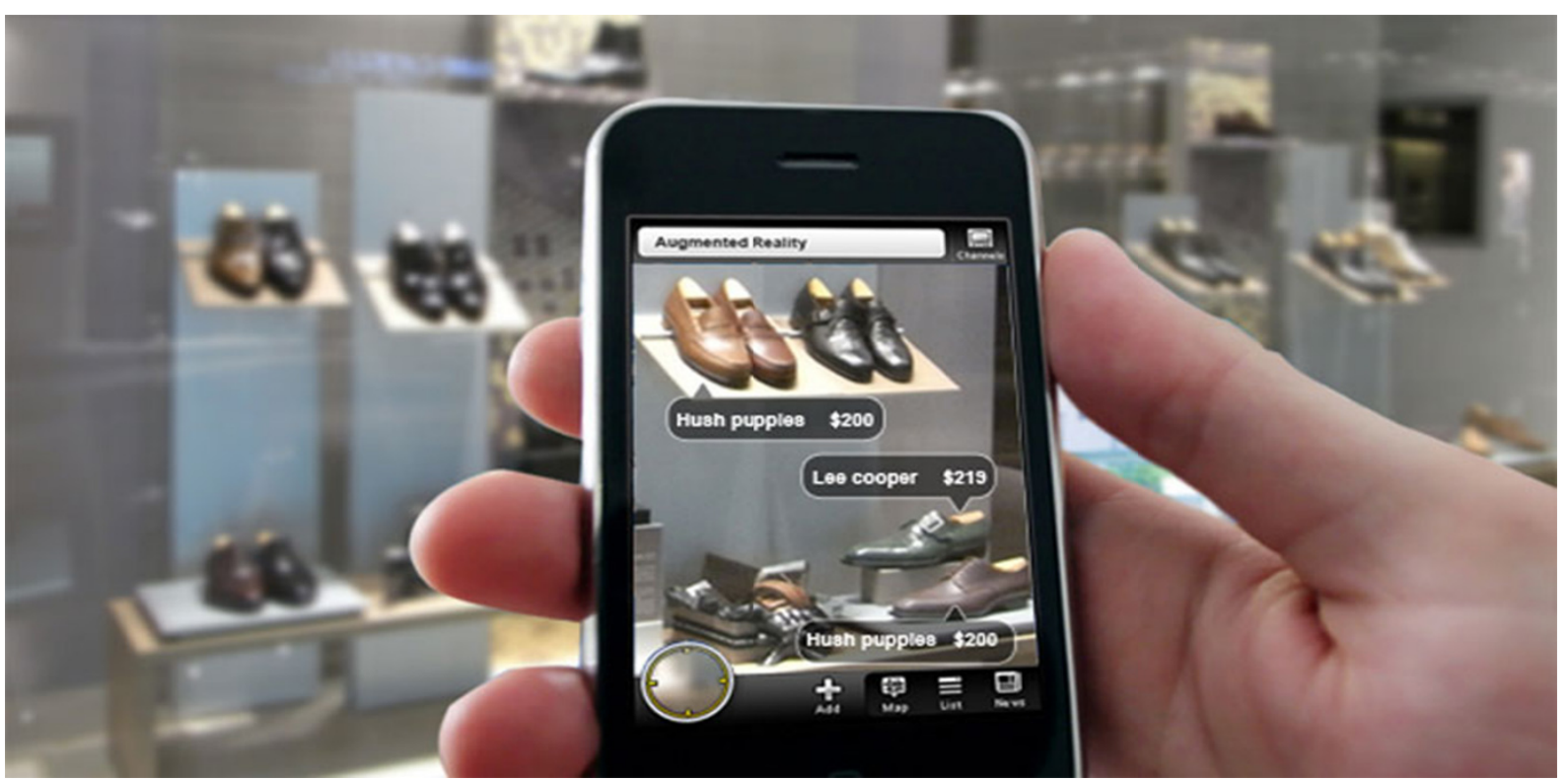

Figure 2. Image based AR system 


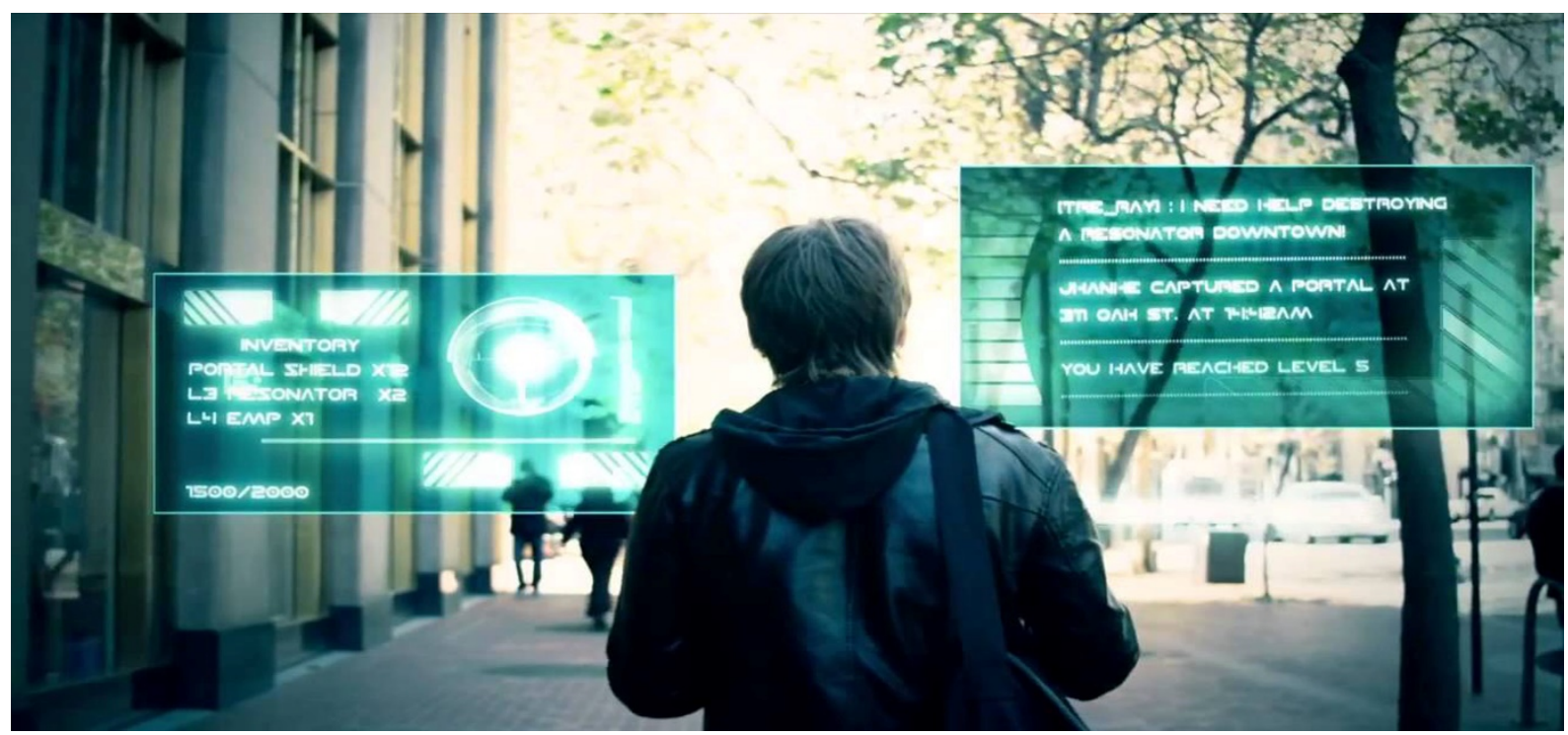

Figure 3. Location based AR system

Image based AR system is divided into two categories as marker based and marker less tracking. In marker based applications, to define the object in real environment and the area in which digital data appear, markers such as QR code are placed in the environment. Marker less tracking practices upon natural features of an object in real environment. As for location based application, location information gathered using GPS (Global Positioning System) is integrated with objects in real environment (See Figure 3).

For location or image based AR technologies to be used, there is a need for some devices. Carmigniani (2011) defines the devices used for AR as display, input devices, tracking and computer. Displaying devices are head-mounted, hand-held display and location (place) based devices. Input devices are tablet and mobile devices. Tracking devices are digital cameras, optical sensors, wireless sensors and markers. And the computer is defined as RAM, processor and graphic card supporting AR application. In his study, Furht (2011) takes sequence of actions into consideration and defines these devices functions as capturing image, recognizing the marker on image, creating digital image by processing it and integrating (virtual-real).

\section{Reality}

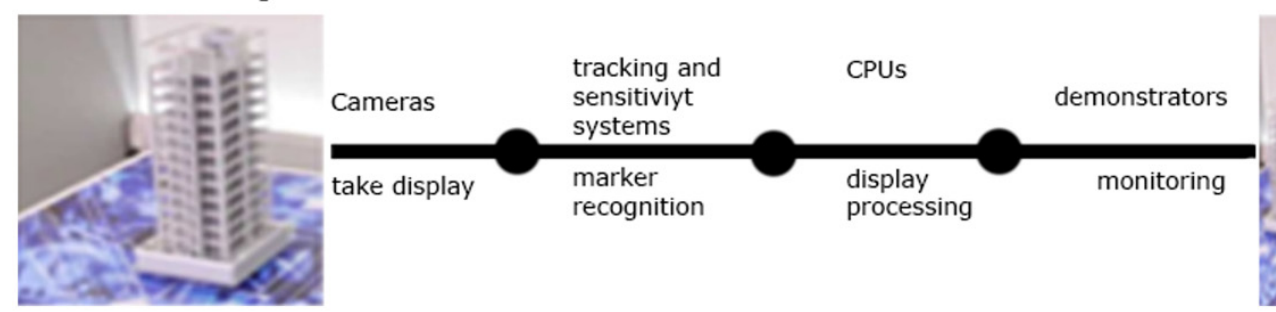

AR

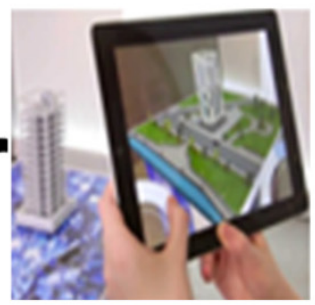

Figure 4. AR working process

An AR marker based working process $\backslash$ according to Furht (2011) is seen on Figure 4. As we approach the working process step by step;

1. Markers (barcode, QR code or the object itself) image is captured with the help of camera (Recognition),

2. Marker is introduced to system via tracking and sensing systems (Tracking),

3. The recognized image is processed by processor and other computer hardware,

4. Head-mounted, hand-held or location (place) based display devices present together real world and digital data (Integration).

Through this process AR applications support learners to experience on real environment and real objects (Cai, Wang, \& Chiang, 2014) and to understand three dimensional structures easily (Nunez et al., 2008). Besides, they allow learning experiences to be put into practice and provide significant opportunities for developing user friendly learning environment (Chat, 2014). There are good deals of researches that bear fruit with the usage of AR in educational process. 
In his study on teaching the protein structures in chemistry class with AR application, Chen (2013) investigated AR applications' contribution to cooperative learning as visualizing device. Again, he studied effect of AR application on learners' performance with cognitive load and visual spatial ability. In the research, students were divided into three groups as students who study merely with text, study with AR application individually and study with AR application cooperatively. As an AR application, Protein Magic Book was used. At the end of the research, learning performance of the group studied with AR application individually was higher than the group studied merely with text. However, among the groups studied with AR application cooperatively there was no significant differences with regard to learning performance. Consequently, it was discovered that AR application did not cause excessive cognitive load but it improves learning performance of the group studied individually as against other conditions.

In the doctoral thesis, Shea (2014) studied students' perception regarding design features of augmented reality mobile game, developed for language learning, and its use. Participants consisted of nine college students who enrolled in Japanese language class. Students used augmented reality mobile game for three weeks. The results obtained showed that augmented reality mobile games enabled to learn language out-of-class and positively improved students desire to communicate in the areas they choose. With this study it was revealed that augmented reality mobile games elasticated out-of-class learning reduced the fear of learning second language and improved personal learning.

Beside international literature there are some Turkish studies in Literature. Since our purpose is to investigate Turkish viewpoint in this study, we searched graduate studies in Turkey. We focus on graduate studies because there very limited number of AR researcher in Turkey, who directly develop or use AR in scientific research settings. There are 61 graduate studies from 2005 to 2016 (see Table 1). Most of these studies belong to engineering and architecture fields. 13 of them are doctorate, 48 of them are master thesis. In the field of educational sciences, there are only five doctorate studies and four master studies. According to Table 1, we can say the number of research on AR is increasing and growing in Turkey. Collecting the experienced researchers views and sharing them future researchers may be a good contribution to AR research field in Turkey.

Table 1. Graduate theses about AR in Turkey *

\begin{tabular}{|c|c|c|c|c|c|}
\hline Year & $\mathrm{PhD} / \mathrm{Ms}$ & Field & Year & $\mathrm{PhD} / \mathrm{Ms}$ & Field \\
\hline 2016 & Ms & Computer Engineering & 2013 & $\mathrm{PhD}$ & Science and Technology \\
\hline 2016 & Ms & Education & 2013 & Ms & Computer Engineering \\
\hline 2016 & Ms & Education & 2013 & Ms & Electric Electronic Engineering \\
\hline 2016 & Ms & Fine Arts & 2013 & Ms & Electric Electronic Engineering \\
\hline 2016 & Ms & Electric Electronic Engineering & 2013 & $\mathrm{PhD}$ & Architecture \\
\hline 2016 & PhD & Education & 2013 & Ms & Architecture \\
\hline 2016 & Ms & Computer Engineering & 2013 & Ms & Computer Engineering \\
\hline 2015 & Ms & Business Administration & 2013 & Ms & Architecture \\
\hline 2015 & PhD & Education & 2013 & $\mathrm{PhD}$ & Computer Engineering \\
\hline 2015 & Ms & Computer Engineering & 2013 & Ms & Computer Engineering \\
\hline 2015 & Ms & Education & 2013 & PhD & Education \\
\hline 2015 & Ms & Industrial Design & 2013 & Ms & Mechatronic Engineering \\
\hline 2015 & Ms & Aircraft Engineering & 2012 & Ms & Architecture \\
\hline 2015 & PhD & Education & 2012 & Ms & Mechatronic Engineering \\
\hline 2015 & Ms & Science and Technology & 2012 & Ms & Electric Electronic Engineering \\
\hline 2015 & Ms & Computer Engineering & 2012 & $\mathrm{PhD}$ & Communication Sciences \\
\hline 2015 & Ms & Communication Sciences & 2012 & Ms & Architecture \\
\hline 2015 & Ms & Architecture & 2012 & Ms & Architecture \\
\hline 2015 & Ms & Industrial Design & 2012 & Ms & Electric Electronic Engineering \\
\hline 2015 & Ms & Computer Engineering & 2011 & Ms & Computer Engineering \\
\hline 2015 & $\mathrm{PhD}$ & Fine Arts & 2011 & Ms & Computer Engineering \\
\hline 2015 & Ms & Fine Arts & 2011 & Ms & Computer Engineering \\
\hline 2015 & Ms & Computer Engineering & 2010 & Ms & Computer Engineering \\
\hline 2014 & Ms & Computer Engineering & 2010 & Ms & Computer Engineering \\
\hline 2014 & Ms & Architecture & 2009 & Ms & Computer Engineering \\
\hline 2014 & Ms & Education & 2009 & $\mathrm{PhD}$ & Communication Sciences \\
\hline 2014 & $\mathrm{PhD}$ & Electric and Electronic Engineering & 2008 & Ms & Architecture \\
\hline 2014 & Ms & Computer Engineering & 2007 & Ms & Electric Electronic Engineering \\
\hline 2014 & Ms & Information and Records Management & 2005 & Ms & Science and Technology \\
\hline 2014 & $\mathrm{PhD}$ & Architecture & 2005 & Ms & Computer Engineering \\
\hline 2013 & PhD & Education & & & \\
\hline Total & & & 61 & & \\
\hline
\end{tabular}

*Source: Council of Higher Education, National Thesis Center, https://tez.yok.gov.tr/UlusalTezMerkezi/ Key word: [augmented reality] 
In one of these studies carried out with AR in education, İbili's (2013) doctorate thesis, on the purpose of viewing the effects of augmented realities usage in geometry teaching on students' achievement and attitude, ARGE3D software is developed. Among the students in two different schools, one experiment and one control group were created in each one of the schools. The control group used textbook and experiment group used ARGE3D software. As a result of the study, there was a significant difference in only one school between posttest and pretest in favour of AR. However, in the other school there was no difference. More researches require for this reason to be found out. Moreover, it was observed that the attitude of students, who take part in the experiment using ARGE3D software, was previously worse, was affected positively and became better.

The other research is Özarslan's (2013) study which aimed to determine the effect of augmented reality and enriched learning material usage on learners' achievement and satisfaction. In this study, OptikAR (Basic Geometrical Optic Experiments) and visually enriched InsectARium (Basic Insect Diversity and Classification Application) materials were developed as AR application. According to the results, learning process performed using OptikAR and InsectARium application, influenced learners' achievement and satisfaction levels positively.

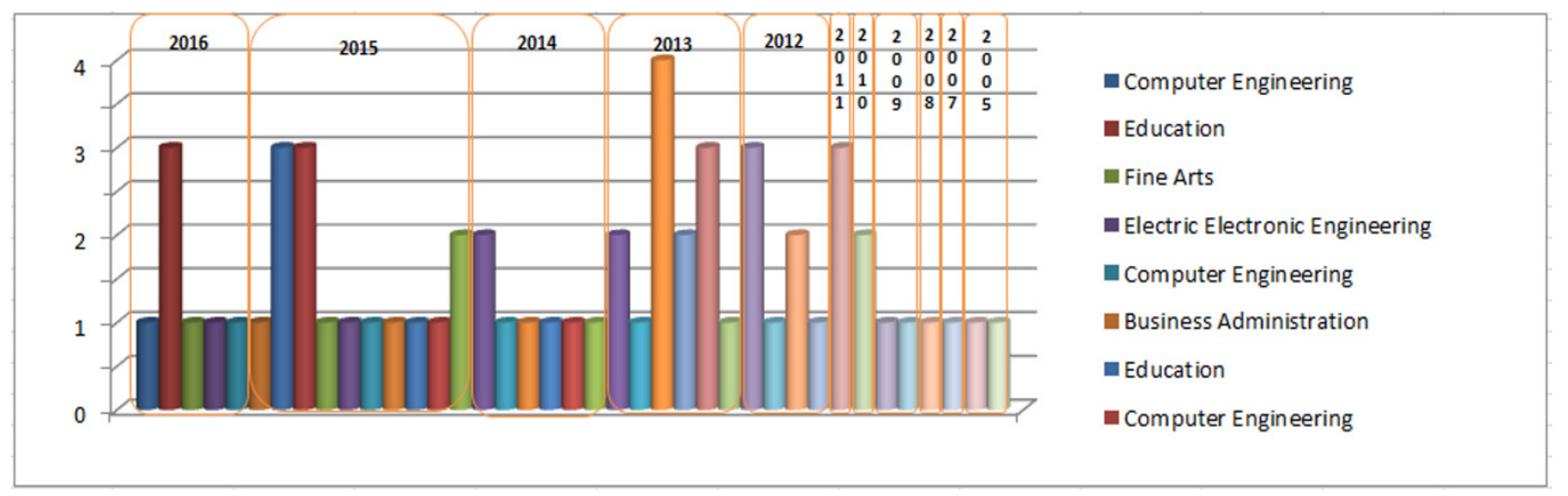

Figure 5. Thesis which studied in the fields by year

Number of the all graduate studies on AR for educational sciences field and the other fields are given by year on the graphic in Figure 5. When Figure 5 is examined, it is seen that the first thesis studies on AG were first realized in 2005, in computer engineering and electrical-electronics engineering fields. Between the years 2005-2014, numbers of the thesis were written in the field of computer engineering increased almost year by year. Therefore, knowledge accumulation of AR in engineering field rises. Then it is possible to say that this knowledge accumulation could contribute to the researchers in educational sciences field and the other fields studying with AR. Accordingly interdisciplinary studies could contribute to AR works in educational sciences field. As for the studies merely seen in educational sciences field, this condition is not true. In Figure 5, it can be seen that there are only two studies in 2013. As it is a study field that needs to be researched, this condition poses a problem for researchers who want to study AR in educational sciences due to lack of experiences, advantage, and findings on the country level.

Seeing that teaching and learning technology and materials have great importance for especially learning process to be performed effectively, considering AR usage in education from constructivist point of view, this technology could provide significant opportunities. AR applications allow of gaining learning experience in accord with constructivist approach and support efficient use of technology and this enables this technology to be used in various fields. AR applications have an extensive area of usage ranging from communication sciences to architecture; from engineering to educational sciences. It could be said that AR has many benefits like concretization and enrichment of abstract or ambiguities concepts and support for cooperative learning, visual imagery in the museums and modeling of objects (İbili, 2013; Özarslan, 2013; Aydoğdu, 2013; Özbay, 2013). However, making use of these benefits depends on AR's proper integration with teaching-learning process. And this integration requires, AR to be examined with educational scientific point of view and applications to be developed, improved and integrated with the current educational system according to this view.

Education acquires different aspects by trying to use the new technology. Without a scientific and holistic approach, new trials may lead new problems depending on the structures of new settings and new technology used. Therefore, it is inevitable that usage of AR technologies may provide advantages and problems at the same time. It is important to do prudential research plans by taking the current experience and knowledge of AR's usage for education into consideration. Likewise in their studies, İbili and Şahin (2013) emphasized that, application potential, limitedness and pedagogic effects of AR teaching software needs to be researched both qualitatively and quantitatively, because of the problems faced during the process of design, development and application of AR. 
In the study, Somyürek (2014) stated that there is a need for experimental findings about the usage of AR applications in educational environments. He states that the results derived from these studies provide necessary information for educators to integrate AR technology into their lectures. Also, it is underlined that the studies focusing on the problems and obstacles encountered in using augmented reality in education would importantly contribute to the field.

In light of this view, when, where and how should augmented reality applications, which are new for our country, in education be used, becomes more of an issue. Based on this need and the information gathered from researchers who accomplished a graduate study on AR, purpose of the study is to find out: Problems, solutions and suggestions from their view points. In order to realize this purpose research questions of the study about augmented reality are:

- On which target group could it be used more effectively?

- On which learning domain (cognitive, affective, and psychomotor) could it be more influential?

- Which learning methods could it be used with?

- What are the problems encountered during designing and application process?

- What are the subjects that need to be researched for using AR more effectively in education?

- In which situations could it be used for education and how should it be designed?

\section{Method}

This is a phenomenological study in the framework of qualitative research. Creswell $(2012,16)$ states that "The literature might yield little information about the phenomenon of the study, and you need to learn more from participants through explanation". This is a research pattern which examines a current event with its own perspective and is used under the conditions that there is a vague border between the event and its context, and there are more than one evidences or data sources (Yıldırım \& Şimşek, 2011). Phenomenological study is a design of inquiry coming from philosophy and psychology in which the researcher describes the lived experiences of participants about a phenomenon as described by them. This description culminates in the essence of the experiences for several individuals who have all experienced the same phenomenon (Creswell, 2014).

\subsection{Participants}

The important consideration within the research is, beyond having only academic knowledge, having experience of using one of the technologies based on AR as a part of scientific research. Accordingly, this study group consists of 12 researchers who study in different universities and departments and also take part in using, developing and implementing process of various augmented reality technologies and applications. They accepted our invitation to voluntarily join to this study. And also, participants had a chance to review their writings before the researchers using this views in this study. At the Table 2, there are AR applications that the participants practiced (Table 2).

Table 2. AR applications that the participants practiced

\begin{tabular}{|c|c|c|}
\hline Participant & Field of Study & Augmented Reality Application Performed \\
\hline $\mathrm{K}_{1}$ & Computer Sciences & $\begin{array}{l}\text { "We used Unity to show our school building on mobile devices; we } \\
\text { combined 3D glasses with AR." }\end{array}$ \\
\hline $\mathrm{K}_{2}$ & Education & $\begin{array}{l}\text { "In sixth grade of elementary class, I developed an AR application on the } \\
\text { subject of teaching geometrical object in math." }\end{array}$ \\
\hline $\mathrm{K}_{3}$ & Education & "I used AR in cultural heritage applications." \\
\hline $\mathrm{K}_{4}$ & Architecture & "I took part in AR application process." \\
\hline $\mathrm{K}_{5}$ & Education & "I have thesis studies done which are on algorithm level." \\
\hline $\mathrm{K}_{6}$ & Architecture & $\begin{array}{l}\text { "I developed a virtual make-up application within the context of my } \\
\text { doctorate thesis." }\end{array}$ \\
\hline $\mathrm{K}_{7}$ & Architecture & $\begin{array}{l}\text { "I developed an urban image mapping and augmented reality application as a } \\
\text { part of my graduate thesis and I practiced it in Galata district in Istanbul." }\end{array}$ \\
\hline $\mathrm{K}_{8}$ & Education & "AR book application." \\
\hline $\mathrm{K}_{9}$ & Education & "I took part in AR application process." \\
\hline $\mathrm{K}_{10}$ & Education & $\begin{array}{l}\text { "In the Augmented Reality application which I developed as a part of my } \\
\text { post graduate thesis, a three dimensional building model is reflected on the } \\
\text { markers that we instructed." }\end{array}$ \\
\hline $\mathrm{K}_{11}$ & Education & $\begin{array}{l}\text { "Animated book applications for the purpose of language teaching." } \\
\text { "I have functionally enriched OptikAR (Basic Geometrical Optic }\end{array}$ \\
\hline $\mathrm{K}_{12}$ & Education & $\begin{array}{l}\text { Experiments) and visually enriched InsectARium (Basic Insect Diversity and } \\
\text { Classification Application) applications." }\end{array}$ \\
\hline
\end{tabular}




\subsection{Data Collection Tool}

In the study, views of the participants were collected via a form that consists of open-ended questions. The form which was preferred for getting in-depth information was developed in accordance with sub problems of the research and review of field literature. In an attempt to check suitability, clarity and practicability of questions, opinions of experts in educational technology and instructional design (3) and assessment and evaluation (1) fields were asked. According to the experts' opinions and offers, the form was modified and finalized. The form consists of 10 questions. The purpose of this form is to answer these questions about augmented reality: 'On which target group could it be used more effectively?', 'On which learning field (cognitive, affective, psychomotor) could it be more influential?', 'Which learning methods could it be used with?', 'What are the problems encountered during designing and application process?', 'What are the subjects that needs to be researched for using it more effectively in educational sciences field?', 'In which situations could it be used for education and how should it be designed?'. The form was electronically posted to 20 researchers and 12 academicians replied.

\subsection{Analysis of Data}

The acquired data was examined using content analysis method. Content analysis is defined as a systematic and iterable technique in which, any words in a text are summarized with smaller content categories (Büyüköztürk et al, 2012). In this study, thematic content analysis was used (Çalık \& Sözbilir, 2014). Under the study, with the purpose of calling attention to both research results and personal experiences of the researchers, data acquired from participants was analyzed as they are the researchers themselves. By coding the raw data acquired, themes were created. The revised data is classified under these themes and repeating frequency of the themes was taken into consideration and the findings were tabulated. With the intention of enhancing the studies reliability, these themes were examined by three different researchers individually, and then they put their heads together and settle the conflict about common themes derived from the data and in this way they reach a mutual understanding on coding and themes (Lincoln \& Guba, 1985; Yıldırım \& Şimşek, 2011).

\section{Results}

\subsection{Researchers Opinions on Using "Augmented Reality (AR)" Notion in Turkish}

Although this research has no purpose from the point of approaching that "what should be the Turkish term for augmented reality (AR)" from a scientific point of view, first, the suggestions for AR's Turkish equivalent are examined to use most suggested term consistently in the study. It was also important to examine participants' own AR definitions. Findings on suggestions about Turkish equivalent term of "Augmented Reality" collected from the researchers are presented in Table 3.

According to findings at Table 3, it is seen that the researchers approved augmented reality, enriched reality and expanded reality terms as a Turkish equivalent for "augmented reality". The participants wrote augmented reality term at most, and expanded reality term at the very least

Table 3. Using "augmented reality (AR)" notion in Turkish

\begin{tabular}{lll}
\hline Using "Augmented Reality (AR)" Notion in Turkish & $\begin{array}{l}\text { Frequency } \\
\text { (n) }\end{array}$ & $\begin{array}{l}\text { Percent } \\
(\%)\end{array}$ \\
\hline Augmented reality & 9 & 75 \\
Enriched reality & 2 & 16.7 \\
Expanded reality & 1 & 8.3 \\
Total & 12 & 100 \\
\hline
\end{tabular}

Participants expressed their reasons for suitability of using augmented reality, with the words below:

"Because it is the first notion I heard and it is the most common one."

"Augmented reality is a better equivalent of this English word. Also it is name of the technology. "

"I prefer this term, because "augmented reality" term ideally expresses the condition of creating a new visual by adding new objects to the real view. "

"Reality concept is augmented in consequence of the process combining the images from the real world with virtually created images."

Statements of the participants who prefer enriched reality notion are below:

"We enrich a reality in AR by adding on supplementary data (image, video, 3D models, etc.) Augmenting the 
current reality is out of the question."

"It could be thought that, augmenting is to improve physical effect of the reality and enriching is to intensify the visual effect of the reality."

By taking these findings into consideration, "Augmented Reality" was the most suitable term according to opinion of the majority of researchers.

\subsection{Researchers Opinions on Teaching Methods, Techniques and Strategies Used in Augmented Reality Environments}

The 28 opinions received from the researchers on teaching methods, techniques and strategies used in augmented reality environments is distributed in 9 themes and given in Table 4.

Among the statements of the researchers about methods, techniques and strategies used in augmented reality environments demonstration is the most popular (see Table 4). Among the methods, techniques and strategies, the participants stated the themes like case study, educational games, cooperative learning, learning via presentation three at a time and learning via research-investigation, discovery learning and problem solving themes two at a time. Researchers' statements on teaching methods, techniques and strategies used in augmented reality environments are below:

"Demonstration is the best method to be used for achieving the objective in AR environments. Individual study is also an option but, information shared by the teacher during demonstration contributes more to cognitive development of students." (Demonstration)

"In today's conditions, it could be used for individual teaching/learning process and cooperative applications mostly. When enriched with supplementary technologies like sensors, goggles and glove, it could provide a chance to learn through experience and act." (Individual Learning and Cooperative Learning)

"I think, using AR with demonstration and case study methods could lead to more success." (Demonstration and Case Study)

"Educational games fit well with AR" (Educational Game)

"Tablets could be used in individual or group study in middle school grade." (Individual Learning and Cooperative Learning)

Table 4. Teaching methods, techniques and strategies used in augmented reality environments

\begin{tabular}{lll}
\hline $\begin{array}{l}\text { Teaching Methods, Techniques and Strategies Used in Augmented } \\
\text { Reality Environments }\end{array}$ & $\begin{array}{l}\text { Frequency } \\
\text { (n) }\end{array}$ & $\begin{array}{l}\text { Percent } \\
(\%)\end{array}$ \\
\hline Demonstration & 6 & 21.4 \\
Individual Learning & 4 & 14.2 \\
Case Study & 3 & 10.7 \\
Educational Game & 3 & 10.7 \\
Cooperative Learning & 3 & 10.7 \\
Presentation & 3 & 10.7 \\
Research-Investigation Teaching & 2 & 7.2 \\
Discovery Teaching & 2 & 7.2 \\
Problem Solving & 2 & 7.2 \\
Total & 28 & 100
\end{tabular}

Based on these findings, it could be said that the researchers' favorite methods could be defined as direct instruction and objectivist. Direct Instruction is a teacher-centered strategy. The teachers are the major information provider and objective source of information and knowledge by transferring facts, rules, concepts etc. (Borich, 2015).

3.3 Researchers Opinions on the Problems Encountered in Developing and Application of AR Environments

The 17 opinions received from the participants on the problems encountered in development and application phases of AR environments. Opinions were categorized under 7 themes, and results were given in Table 5.

When we look at Table 5, among the problems encountered in developing and applying of augmented reality environments, hardware limit comes into prominence. The researchers express hardware limits as such statements; "in terms of technical equipment, it is very hard to use AR materials in computer labs", "there is a matter of high processor 
power requirement in mobile devices", "in one of the studies we are working on, we have to carry out the study on my own personal computer due to hardware problems".

As a result of the analysis, among the solutions to hardware limit problem, using advanced hardware is the prominent solution offer. Computers, tablets, phones etc., should have high capacity hardware such as RAM and graphic card, if they are included in AR application developing and application process. Otherwise, problems suchlike the participants statements will be confronted. As well as hardware limit problems, unnecessary use of AR environments is among the popular statements of the participants.

Researchers' statements on development and application of augmented reality environments are below:

"When subjects which could be presented effectively with classical methods, are taught to groups with AR, I think that AR environment development is wrong resource management." (Unnecessary Use of AR Environment)

"Because of camera specifications, it creates photopsy during exposure and this leads markers not to be sensed by AR algorithms." (Photopsy during exposure when camera is sensing the marker)

"Necessity of seeing the full marker, in case the square markers are used." (The full marker is not seen because the camera is not recognized).

Table 5. The problems encountered in developing and application of AR environments

\begin{tabular}{|c|c|c|c|}
\hline Problems & Solutions & $\begin{array}{l}\text { Frequency } \\
\text { (n) }\end{array}$ & $\begin{array}{l}\text { Percent } \\
(\%)\end{array}$ \\
\hline Hardware limitations & Using more advanced hardware & 7 & 41.2 \\
\hline Software limitations & $\begin{array}{l}\text { Requires using correct algorithm and well developed } \\
\text { software skills. }\end{array}$ & 3 & 17.6 \\
\hline Unnecessary Use of AR Environment & $\begin{array}{l}\text { Using of tools, methods and technics suitable of } \\
\text { subject }\end{array}$ & 2 & 11.7 \\
\hline $\begin{array}{l}\text { The full marker is not seen because the } \\
\text { camera is not recognized }\end{array}$ & $\begin{array}{l}\text { Unity program can be used and the technical support } \\
\text { can be taken from Vuforia company. }\end{array}$ & 1 & 5.9 \\
\hline $\begin{array}{l}\text { Photopsy during exposure when camera } \\
\text { is sensing the marker }\end{array}$ & Cameras should be adjusted manually. & 1 & 5.9 \\
\hline $\begin{array}{l}\text { Dynamic and static errors because of } \\
\text { tracking system }\end{array}$ & $\begin{array}{l}\text { Different sensors should be used /Multiple sensors } \\
\text { should be used together. }\end{array}$ & 2 & 11.8 \\
\hline Not to take learners' attention & Teacher supported solutions & 1 & 5.9 \\
\hline Total & & 17 & 100 \\
\hline
\end{tabular}

According to operating logic of AR, first images captured with camera should be introduced to the system. For the problems like brightness, sharpness, recognizing of the full marker, based on camera settings, AG supporting programs like Unity could be used or camera could be set manually. And Azuma (1997) states another problem in his research, which are the dynamic and static errors that originate from tracking system. There problems are about polygon numbers of modeling (polygon pieces that compose the model) from technical aspect. Sensor (detector) should be modified to solve these kind problems. Researchers' statements on problems deriving from tracking systems and the remedy are below:

"Generally, AR is easily practiced indoors. But the hardship is decrease of frame per second due to crowd of models polygon numbers. Azuma defines this as dynamic errors. There is a need for other sensors (GPS, IMU, camera) to track the user because it is hard to use markers outside specifically. Cheap sensors having less sensitivity are the problem here. As the sensitivity is lesser, tracking gets harder (In Azuma's words, static errors). Solution for this error is to optimize model polygon numbers and to try getting better results by using different sensors together (sensor fusion)" (Dynamic and static errors derived from tracking systems).

\subsection{Researchers Opinions on the Subjects That Needs To Be Researched Before AR's Integration to Education}

Researchers' 22 opinions on the subjects that need to be researched before AR's integration to education were distributed among 13 themes and given in Table 6.

Table 6 shows that researchers opinions on the subjects that needs to be researched before AR's integration to education mostly includes creating digital content and defining AR's educational and economic benefits.

One of the participants who took part in the research clearly stated this situation as; "first of all, the content needs to be defined perfectly and a good scenario for the lesson application needs to be built. We see AR's use for education as an educational game but a game with a weak scenario doesn't create many demands and aspects of the effect and ratings could be measured with pilot studies. After all, AR is costly and if the educational effect is low, all of the expense would go for nothing" 
The issues which were less mentioned by the participants are; developing animation, defining the suitable teaching methods when integrating to education, trying to eliminate the psychological barriers of human-interface interaction, instructing the teachers, integration methods of AR to the curriculum and defining the principles and methods that are proper to AR.

Table 6. The subjects that needs to be researched before AR's integration to education

\begin{tabular}{lll}
\hline The Subjects That Needs To Be Researched Before AR's Integration to & $\begin{array}{l}\text { Frequency } \\
\text { Education }\end{array}$ & $\begin{array}{l}\text { Percent } \\
(\%)\end{array}$ \\
\hline Creating digital content & 4 & 18.2 \\
Defining AR's educational and economic benefits & 3 & 13.6 \\
Discussion of the necessity AG for problems & 2 & 9.0 \\
Authenticity level of the models & 2 & 9.0 \\
The adequacy of hardware and software infrastructure & 2 & 9.0 \\
Instructing students & 2 & 9.0 \\
Developing animation & 1 & 4.6 \\
Defining the suitable teaching methods when integrating into education & 1 & 4.6 \\
Trying to eliminate the psychological barriers of human-interface & 1 & 4.6 \\
interaction & & 4.6 \\
Instructing teachers & 1 & 4.6 \\
How to integrate AR into curriculum & 1 & 4.6 \\
Defining the principles and methods that are proper to AR & 1 & 4.6 \\
Needs to be done to ensure collaboration with other disciplines & 1 & 100 \\
Total & 22 & \\
\hline
\end{tabular}

\subsection{Researchers Opinions on Proper Use of AR Applications}

The 35 statements received from the participants on proper situations for the use of augmented reality applications, were distributed among 8 themes and given in Table 7.

Table 7. Proper use of AR applications

\begin{tabular}{lll}
\hline Proper Use of AR Applications & $\begin{array}{l}\text { Frequency } \\
(\mathrm{n})\end{array}$ & $\begin{array}{l}\text { Percent } \\
(\%)\end{array}$ \\
\hline Instructions and manuals for an individual showing the use of a specific object or & 11 & 31.4 \\
actions to be taken in a specific condition & 10 & 28.5 \\
Tutorials & 9 & 25.6 \\
Using as a tool in service, marketing sector and product overview & 1 & 2.9 \\
Experimental Simulations & 1 & 2.9 \\
Using in different disciplines & 1 & 2.9 \\
Problem solving and exercising & 1 & 2.9 \\
In order to increase motivation in younger age groups & 1 & 2.9 \\
Collaborative educational practices and educational fiction related to place & 35 & 100 \\
Total & & \\
\hline
\end{tabular}

When Table 7 is examined, most common opinions on proper use of AR applications are respectively; instruction and manual for an individual showing the use of a specific object or actions to be taken in a specific condition, using as a tool for teaching applications, also using as a tool in service, marketing sector and product overview.

\subsection{Researchers Opinions on Limits of AR Use}

The 9 statements received from the participants on limits of augmented reality use. They were categorized under 5 themes and given in Table 8.

Table 8. Limits of AR Use

\begin{tabular}{llc}
\hline Limits of AR Use & $\begin{array}{l}\text { Frequency } \\
(\mathrm{n})\end{array}$ & Percent (\%) \\
\hline Limits which derives from markers & 4 & 44.5 \\
Unsuitability for every area and subject & 2 & 22.2 \\
Limits originating from hardware dependence & 1 & 11.1 \\
Limits originating from the effort and time spent & 1 & 11.1 \\
Limits originating from lack of using technology by teachers and students & 1 & 11.1 \\
Total & 9 & 100 \\
\hline
\end{tabular}

When we look at Table 8, participants' statements are mostly about: AR application limit which derives from markers. The researchers statements are; algorithms which are used in AR markers need to be developed because in AR applications, during camera exposition photopsy occurs and this obstructs the marker sensing, markers used in AR 
work in a limited environment and using too many markers could lead to false identification and in marker-based systems the camera could not correctly sense the instructed marker and this leads to image loss. Participants' statements about the other limits are:

"Particularly hardware dependence limits AR technology." (Limits originating from hardware dependence)

"Although AR use is increasing, it only presents visual data and it could not be productive considering the time spent." (Limits originating from the effort and time spent)

"I think that this situation remains limited to substantial subjects. It has a narrow area of use in social sciences." (Unsuitability for every area and subject)

\subsection{Researchers Opinions on Points to Take Into Consideration When Designing AR Application}

Researchers' 22 opinions on points to take into consideration when designing AR application were collected under 10 themes and given in Table 9.

Table 9. Points to take into consideration when designing AR application

\begin{tabular}{lll}
\hline Points To Take Into Consideration When Designing AR Application & $\begin{array}{l}\text { Frequency } \\
\text { (n) }\end{array}$ & Percent (\%) \\
\hline Suitability for the purpose & 5 & 22.7 \\
Virtual objects that reflect reality & 3 & 13.7 \\
Providing efficiency in education process & 3 & 13.7 \\
Suitability for target group & 3 & 13.7 \\
Interaction with user interface and user & 2 & 9.1 \\
Usability & 2 & 9.1 \\
Resolution of the image, displaying the image of same duration every time & 1 & 4.5 \\
Technical support should be provided & 1 & 4.5 \\
There shouldn't be image loss & 1 & 4.5 \\
Should be effective and efficient for learners & 1 & 4.5 \\
Total & 22 & 100 \\
\hline
\end{tabular}

Findings at Table 9 show that statements of the participants on points to take into considerations when designing AR applications are mostly about suitability for the purpose. Then they remark that it should be appropriate for the characteristics of target group and productivity should be increased with virtual objects that reflect reality. Participants' statements on the points to take into consideration when designing AR application:

"First, its suitability for the characteristics of target group is important." (Suitability for target group)

"Because it's an education based application, ease of use has primary importance." (Usability)

"If the image is constantly being lost, resolution is the real problem" (Resolution of the image, displaying the image of same duration every time)

"AR applications must be prohibited for all lessons and subjects. They must be used only to solve teaching problems that should be eased with AR (For specific subjects). "Otherwise, when it is used more for affective learning then cognitive development, the effect derived from advancing technology will dissolve in time and negatively effect on affective learning." (Efficiency, Suitability for the Purpose)

3.8 Researchers Age Group Choice for the Future Augmented Reality Research

The 15 statements received from the participants on age group choice for the future research are distributed in 8 themes and given in Table 10.

Table 10. Age group choice for the future augmented reality research

\begin{tabular}{lll}
\hline Age Group Choice For The Future Augmented Reality Research & $\begin{array}{l}\text { Frequency } \\
\text { (n) }\end{array}$ & Percent(\%) \\
\hline No age limit (Appropriate for all age groups) & 11 & 73.4 \\
Elementary School & 2 & 13.3 \\
Secondary School & 2 & 13.3 \\
Total & 15 & 100 \\
\hline
\end{tabular}

The researchers mostly state that augmented reality is appropriate for all age groups and some of them state that it is appropriate for elementary school and secondary school grade (see Table 10). According to the statements of participants; there is no age limit, it draws everyone attention, with a proper design it could be used for every age group 
and it is appropriate for every age groups which are taught to use computer, mobile device or the other electronic equipment. Also researchers remark that they will choose sample age groups in elementary and middle school grade for the future research.

\subsection{Researchers Learning Domain Preferences for the Future Augmented Reality Research}

Researchers 21 statements on augmented realities contribution to learning domains for the future research are distributed to 3 themes and given in Table 11 .

Table 11. Learning domain preferences for the future augmented reality research

\begin{tabular}{lll}
\hline Learning Domain Preferences for The Future Augmented Reality Research & $\begin{array}{l}\text { Frequency } \\
\text { (n) }\end{array}$ & $\begin{array}{l}\text { Percent } \\
(\%)\end{array}$ \\
\hline Cognitive Domain & 9 & 42.86 \\
Affective Domain & 6 & 28.57 \\
Psychomotor Domain & 6 & 28.57 \\
Total & 21 & 100
\end{tabular}

According to researchers (see Table 11), the learning domains which contribute to the future research on augmented reality most are cognitive, then affective and psychomotor domain. The sample statements, received from the participants on augmented realities contribution to learning domain in the future research are below:

"I think that it will contribute to cognitive development. I consider, it is proper for creating schemes that are in students' mind." (Cognitive Domain)

"It could be said that it contributes more to cognitive development from the point of learning and assimilating the knowledge."(Cognitive Domain)

"It is more effective for psychomotor development. Because it allows to develop a skill." (Psychomotor)

"It contributes more to cognitive development, because it leads mental activity during learning to a higher level." (Cognitive Domain)

"AR's success depends on, effectiveness of AR material and teachers using this AR material efficiently. With these two conditions in company, AR material could contribute to cognitive and affective development of students." (Cognitive and Affective Domain)

\section{Discussion, Conclusion and Suggestions}

The purpose of this study is to come through thematic conclusions that could be considered for the future research and contribute to development of the field from point of view of the researchers who practically conducted a study on AR and to answer these questions; 'On which target group could it be used more effectively?', 'On which learning domain (cognitive, affective, psychomotor) could it be more influential?', 'Which learning methods could it be used with?', 'What are the problems encountered during designing and application process?', 'What are the subjects that needs to be considered for using it more effectively in educational sciences field?', In which situations could it be used for education and how should it be designed?'. Within this perspective, the findings are discussed by contrasting them with body of literature and proposals are tried to be brought forward.

When Turkish literature was searched, it was seen that there are different terms used for "Augmented Reality (AR)" in Turkish. In his study, Bostanc1 (2014) claimed that there was no augmentation for a reality but it was enriched by adding supplementary information to reality and therefore he called AR as Enriched Reality. Özarslan (2013) stated that reality was not enriched or quantitatively increased, our perception of reality transiently expanded and therefore he named the notion as Expanded Reality. Some researchers as Somyürek (2014), Hacıhasanoğlu (2012) and Akbaş (2011) used Augmented Reality concept because reality was augmented through interaction of virtual images with real images.

In the research it was understood that the participants generally use the term AR in Turkish as "enriched reality", "expanded reality" and mostly "augmented reality". The participants remarked their preference for the use of augmented reality notion by such statements; "I prefer to use "augmented reality" because it clearly explains the meaning of creating a new image by adding new objects to real image", "Augmented means to enhance and to reproduce and it ideally expresses AR". Although Turkish equivalent of AR notion has some fractional differences, it has something common with Azuma's (1997) perspective; in AR there are virtual world and real world, they combine concurrently and they interact with each other. Augmented reality was chosen for the purpose of using a common notion for body of literature. 
Among methods, techniques and strategies used in augmented reality environments, the participants chose demonstration method mostly. Demonstration is a method of teaching, by applying a technique or an operation, operating the equipment, explaining first by indicating, then practicing and applying (Özer-Özkan \& Acar-Güvendir, 2013).

This method is widely used for performing essential application to explain specific information and convert it to a skill and raise a behavior in application level (Çobanoğlu, Kaplan, \& Tok, 2012). In their research Akbıyık and Seferoğlu (2012) state that the most common method used by primary school information technologies teachers is demonstration. In his research, Yeşilyurt (2013) stresses that teachers used demonstration method use it to make knowledge permanent and to objectify the subject. AR applications support individual learning, cooperative learning (Squire and Jan, 2007), individual learning that assumes control of self-learning environment (Elford, 2013) and omnipresent learning. In applications supported with demonstration method, students learn with materials without time and space limit. The noteworthy point here is that, method and technique must undergo a change according to purpose of study and prepared content. The results show that, the methods stated mostly by the researchers rank as direct instruction and objectivist paradigm. In the future studies, it is thought that interdisciplinary approaches will contribute to use of both application and richer teaching methods.

Technology, renovates itself for troubleshooting various problems that people encountered in their lives. AR technology is a software and hardware platform that continues to develop within this context. Software and hardware has a close relationship that is to say without software, functionality of hardware is limited and vice versa. To realize their potential, hardware and software must work together. It could be said that, the problems generating from camera, tracking and sensing systems, processors, markers and indicators in AR hardware system, could affect software. In his study, Ünal (2013) underlines that many problems such as hardware, software, connection, GPS and tracking arising from newness of AR technology, are encountered. Azuma's (1993) study stresses on tracking systems and indicates some features to be taken into consideration for not making mistakes while displaying. These features are noted below.

- Error margin of position and direction data should not exceed 1-2 mm value.

- Merging duration (latency of tracking system) of a real-world image and digital image should be kept low (It should not exceed 2 milliseconds, as recommended).

- Tracking system should work indoor and outdoor for long distances.

As a result of the study, it is indicated as a significant issue that among the problems encountered during developing and application of augmented reality environments, hardware and software limitedness stand out. As the past researches are taken on board, it could be said that hardware inadequacy is one of the main problems that hinders the process of AR's integration with education. Çakar and Emirli (2012) remark that the most important factor which limits AR technology is hardware and to resolve the limitedness there is a need for a computer with a advanced hardware specifications. Consequently, in integration of AR technology with education providing technical infrastructure requirements becomes more of an issue. For the future researches or projects it should be noted that designing, developing, application processes requires a considerable amount of fund.

Technologies integration with education is defined as using proper technology with the aim of enhancing the learners' progress (Hew \& Brush, 2007). There are some points to be noted for learning environment supported with technology. As Newby, Stepich, Lehman and Russell (1996) state that, teaching content should be rich, adequate and effective. As one of these technologies, when Somyürek, Atasoy and Özdemir's (2009) research on integration of smart boards with schools, is analyzed it is seen that teachers have not technical and pedagogical knowledge and also there is a shortage of digital content. In the research conducted, researchers' remarks mostly include creating of digital content about the integration of augmented reality with education and which must be initially researched. Technologies enabling real world to concurrently merging with digital content are intended to be developed with AR technologies (Haller, Billinghurst \& Thomas, 2007). With the advancing technology, it will be a crucial action to develop Augmented Reality (AR) technology which offers rich multimedia content by adding a digital layer to real world images and to work up 3D interactive course books and virtual learning objects (İbili, 2013). In augmented reality, by manipulating in digital content both on computer and on paper, the technology serves as a bridge between digital world and the paper (Guimbretière, 2003). Considering this potential, there is a need for contents and applications that enable this technology to be integrated with current courses. Getting a good outcome from the contents and applications that will be developed, lead this technology to spread and advance. Owing to this, such problems as not being able to integrate the tablets that handed out at school with education and thus causing a trouble could be prevented within the body of literature (Ar \& Akgün, 2014)

When designing learning and teaching process one of the first operations to be done is to specify learning outcome. Specifying learning outcome is one of the basic operations in teaching design and it directs the designing process 
(Krathwohl, 2002). Determining what kind of content to be taught to learners sets the achievement of this process (Erişti \& Küçük, 2006). Different learning outputs require different learning design. Therefore, it is considered that the offers which aim to determine for which educational case AR could be used, will contribute to the study. The participants' mostly state, augmented reality should be preferred for instructions and manuals for an individual showing the use of a specific object or actions to be taken. The characteristics of a manual or an instruction express the conditions in which it is known what to do at every step. Steps within the process do not usually change. Car driving is an example for this condition. It is suggested by the participant to use is in such conditions which have operation sequence. However, it should be considered that the participants thoughts are bounded by their profession and applications performed. Conducting researches on defining necessities of fields and practices to which AR technology help contributes to the field.

AR technology suffers from such restraints as high resolution, color depth, brightness, contrast, field of view, focal depth, marker issues. In a research conducted, according to statements of the participants, AR applications are commonly limited by marker use and marker sensing. Besides, marker tracking systems has a crucial role in AR. The basic tracking method is marker-based system. In this type of systems, the process is initiated by introducing a readily-prepared black and white barcode to the system. When the application detects the barcode, the digital data prepared is overlaid on the real object. Special figures such as barcode and QR codes used in application create markers. Marker-based tracking system is the most commonly used tracking system with its usability and low cost (Münir, 2010). Though, Welch and Foxlin (2002) state that there are some issues regarding to markers and tracking systems of AR. Although this issue has remained unsolved for the past ten years, it is important for the researchers who are concerned about the subject. Moreover, for AR to be accepted as a digital assistant of daily living, subjects covering user interface, cost, weight (for wearable technologies), power consumption, ergonomics, appearance, tracking and sensitivity should be discussed (Van Krevelen \& Poelman, 2010).

One of the findings used in the research is suggestions about development of AR applications. As the other teaching materials, AR applications should be fit for purpose and be formed in accordance with the needs as well. Effectiveness of educational activities is directly proportionate to originality of teaching materials used and expediency of them for learners' purpose. In the research, the participants point out that during designing process, "AR application should be prepared according to the predetermined idea".

With reference to the Horizon Report in 2014, educational technologies are defined as tools and resources used for improving teaching, learning and creative examination. Among the new popular tendencies and technologies at the present time intended to use for educational process, there are learning analysis, cloud computing, mobile applications, game-based learning, simulations, virtual worlds and augmented reality (Çağıltay \& Göktaş, 2013). The aim for these new technologies to be used in schools is to enhance learning to the ultimate level. On the basis of the 2011 Horizon Report, Brown and Green (2013) state that game-based learning and augmented reality will have a great effect on K-12 students in the near future. From the findings of this research, it could be inferred that augmented reality is suitable for all age groups but some of the participant draw special attention to primary and secondary school. This condition could be regarded as a similar outcome with foreign literature. In accordance with the participants opinions, statements such as; "it engages young age groups attention until high school", "It is suitable for AR to be used for individuals in primary and secondary school degree. Because it is hard and laboring to teach abstract concepts to this age group" indicate that augmented reality is applicable for all age groups and it is referred to developing of applications especially for primary and secondary school.

The main purpose of using AR has been for explaining a topic of interest as well as providing additional information. AR educational games and AR for lab experiments are also growing fields (Bacca, Baldiris, Fabregat, \& Graf, 2014). Perey and Wrangler (2011) reveal that augmented reality improves acumen and increases attendance of the learners in all age groups and disciplines ranging from geography and physics, to language and culture. The individuals are knowledgeable, prudential and skillful in their daily living. Therefore, educators classify the features that they teach to students as fields of cognitive, affective and psychomotor learning (Erişti \& Küçük, 2006). Neumann and Majoros (1998) indicate that possible advantages for augmented reality users in cognitive domain are; access to information, reduced error probability, increased motivation, simultaneous education and performance. In the conducted research, the participants state that they specify the future research targets to be reached related to augmented reality in compliance with first cognitive, then affective and psychomotor learning domains. These learning domains are hand in and glove with each other. Consequently it could be said that applications for only one learning domain or multiple learning fields at the same time will be developed with AR.

With all of these findings which are obtained from comments of the practitioners above, about the Augmented Reality in Turkey as a general subject, the suggestions mentioned below are tried to be expressed clearly. When considering these researches one must take notice of their limitedness that graduate researches within this field are focused on, and 
only two of these researches are in educational sciences field and they are predicated upon opinions of 12 researchers. On the basis of the findings, here are the concluded suggestions:

For the Turkish equivalent of this concept in the literature and as a finding of this research, the most expressed suggestion is "Augmented Reality". To build a common language for the future research, this term is offered.

In educational sciences field it is seen that, AR is mostly offered to be used with demonstration method and methods that could be described as objectivist. AR applications which use these methods should be developed. However, only two of the participants study in educational sciences field, this is a restriction and should be considered. Along with this methods, by organizing an interdisciplinary research team, projects which will be more effective and useful and make use of constructivist methods such as anchored learning, problem-based learning, project-based learning, inquiry based learning and scavenger hunting etc., may be carried out.

The participants suggest using AR technology particularly in preparation of instructions and manuals. Nevertheless, it should be noted that most of the AR practitioners study in fields different from educational science. Right alongside of preparing instructions and manuals using AR, contents and applications should be developed for teaching in a specific field and projects and researches should be conducted about the subject.

In AR applications to be developed, hardware and software should be up to date and software-hardware balance should be principally considered. Planning should be done according to the opportunities that are given or could be given to test subjects for experimental studies.

Although AR applications are suitable for all age groups, it could be said that the only age group which is capable of using this technology and these applications widely (within the scope of tablets that handed out for FATIH project), is high schoolers. Besides, it should not be forgotten that the applications developed for primary and secondary school students, may appeal to a wide target group.

While developing contents, applications and teaching materials, affective and psychomotor fields could be targeted as well as the popular cognitive field. On the other hand, content and applications could be developed according to advantages covering multiple fields. It should be noted that AR technology also supports mobility.

For AR technology to be integrated with educational science effectively, development of contents and applications which lead to more influential, productive and interesting learning outcome should be prioritized. Contents and applications that improve learning quality and success will surely contribute to development and popularization of AR. Again contents and applications developed, will allow learners to use their tablets and smartphones more actively.

\section{References}

Akbaş, M. F. (2011). Development of 3-D augmented reality software interface on mobile devices. Master Thesis. Ege University, İzmir.

Akbıyı, C., \& Seferoğlu, S. S. (2012). Instructing ICT lessons in primary schools: teachers' opinions and applications. Educational Sciences: Theory \& Practice, 12(1), 417-422.

Akgün, Ö. E., Aydın, F., Horzum, F., Özen, S., Bakırcı, S., Gönültaş, A., ... Önder, A. İ. (2014). Geliştiren ve uygulayanların eğitimde öğretim materyali kulanımıyla ilgili görüşleri. II. Sakarya'da Eğitim Araştırmaları Kongresi Bildiriler Kitabl. http://www.egitim.sakarya.edu.tr/sites/egitim/file/1406067910-seak-bildiriler-kitabi-pdf.pdf

Akkoyunlu, B. (2002). Educational technology in Turkey: Past, present and future. Educational Media International, 39(2), 165-174. https://doi.org/10.1080/09523980210155352

Ar, K. Z., \& Akgün Ö. E. (2014). Fatih projesi kapsamında dağıtılan tabletlerin ögretmenler ve ögrenciler tarafindan kullanılma durumlarına ilişkin öğretmen görüssleri. II. Sakarya'da Eğitim Araştırmaları Kongresi Bildiriler Kitabı. http://www.egitim.sakarya.edu.tr/sites/egitim/file/1406067910-seak-bildiriler-kitabi-pdf.pdf

Arslan, B. (2003). Bilgisayar destekli eğitime tabi tutulan ortaöğretim öğrencileriyle bu süreçte eğitici olarak rol alan öğretmenlerin BDE’ e ilişkin görüşleri. The Turkish Online Journal of Educational Technology, 2(4), 67.

Aydoğdu, D. (2013). Usage of augmented reality technologies a case study: augmented reality in museums. Master Thesis. Yaşar University, İzmir.

Azuma, R. (1993). Tracking requirements for augmented reality. Communications of the ACM, 50-51. https://doi.org/10.1145/159544.159581

Azuma, R. (1997). A survey of augmented reality. Presence: Teleoperators and Virtual Environments, 6(4), 355-385. https://doi.org/10.1162/pres.1997.6.4.355 
Bacca, J., Baldiris, S., Fabregat, R., \& Graf, S. (2014). Augmented reality trends in education: a systematic review of research and applications. Journal of Educational Technology \& Society, 17(4), 133.

Borich, G. D. (2015). Observation skills for effective teaching: Research-based practice (seventh edition). New York: Routledge.

Bostanc1, G. E. (2014). User tracking methods for augmented reality applications in cultural heritage. Doctorate Thesis. University of Essex, United Kingdom.

Bound A. C., Haniff, D. J., Baber, C., \& Steiner, S. J. (1999). Virtual reality and augmented reality as a training tool for assembly tasks, information visualization. Institute of Electrical and Electronics Engineers, 32-36.

Brown, A., \& Green T. (2013). Issues and Trends in Instructional Technology: Despite Lean Times, Continued Interest and Opportunity in K-12, Business, and Higher Education. In M. Orey, S. Jones \& R. Branch (Eds.), Educational Media and Technology Yearbook, (Vol. 37, pp. 55-71). New York: Springer. [R\&T]. https://doi.org/10.1007/978-1-4614-4430-5_5

Büyüköztürk, Ş., Kılıç-Çakmak, E., Akgün, Ö. E., Karadeniz, Ş., \& Demirel, F. (2012). Bilimsel Araştırma Yöntemleri. Ankara: Pegem Akademi.

Çağıltay, K., \& Göktaş, Y. (2013). Ögretim Teknolojilerinin Temelleri: Teoriler, Araştırmalar, Eğilimler. Ankara: Pegem Akademi.

Cai, S., Wang, X., \& Chiang, F. K. (2014). Case study of augmented reality simulation system application in a chemistry course. Computers in Human Behavior, 37, 31-40. https://doi.org/10.1016/j.chb.2014.04.018

Çakal, M. A., \& Emirli, E. B. (2012). Artırılmış gerçeklik teknolojisi. Kuzey Doğu Anadolu Kalkınma Ajansı, TRA1. Retrieved September 15, 2017, from http://www.kudaka.org.tr/ekler/fa254-artirilmis_gerceklik_teknolojisi. pdf

Çalık, M., \& Sözbilir, M. (2014). Parameters of content analysis. Education and Science, 39(174), 33-38. https://doi.org/10.15390/EB.2014.3412

Carmigniani, J. (2011). Augmented reality methods and algorithms for hearing augmentation. Master Thesis. Florida Atlantic University, Florida.

Chat, N. L. (2014). How to get augmented reality into the classroom. Tablets for schools. Retrieved March 12, 2016, from http://www.tabletsforschools.org.uk/how-to-get-augmented-reality-into-the-classroom/

Chen, Y. C. (2013). Learning protein structure with peers in an AR-enhanced learning environment. Doctorate Thesis. University of Washington, USA.

Çobanoğlu, N., Kaplan, İ. E., \& Tok, H. (2012). Türkiye'de öğretim yöntemleri üzerine yapılan çalışmaların içerik analizi. 2. Ulusal Eğitim Programları ve Öğretim Kongresi, Bolu.

Creswell, J. W. (2012). Educational research: Planning, conducting, and evaluating quantitative and qualitative research (Fourt Edition). New York: Pearson.

Creswell, J. W. (2014). Research design: Qualitative, quantitative, and mixed methods approaches (Fourth Edition). Los Angeles: SAGE.

Elford, M. D. (2013). Using tele-coaching to increase behavior-specific praise delivered by secondary teachers in an augmented reality learning environment. Doctorate Thesis, University of Kansas, Kansas.

Erişti, B., \& Küçük, M. (2006). Kuralların öğretimi. İçinde A. Şimşek (Ed). İçerik türlerine dayalı öğretim (ss. 71-101). Ankara: Nobel

Furht, B. (2011). Handbook of Augmented Reality. London: Springer. https://doi.org/10.1007/978-1-4614-0064-6

Graham, M., Zook, M., \& Boulton, A. (2013). Augmented reality in urban places: contested content and the duplicity of code. Transactions of the Institute of British Geographers, 38(3), 464-479. https://doi.org/10.1111/j.1475-5661.2012.00539.x

Guimbretière, F. (2003). Paper augmented digital documents. In Proceedings of the 16th annual ACM symposium on user interface software and technology (pp. 51-60). ACM. https://doi.org/10.1145/964696.964702

Hachasanoğlu, İ. (2012). Representation of urban image in the information age: A case study of Galata. Master Thesis, İstanbul Technical University, İstanbul.

Haller, M., Billinghurst, M., \& Thomas, B. (2007). Emerging Technologies of Augmented Reality: Interfaces and Design. Idea Group Publishing. https://doi.org/10.4018/978-1-59904-066-0

Hefzallah, İ. M. (2004). The new educational technologies and learning: Empowering teachers to teach and students to 
learn in the information age. Illinois: Charles C Thomas Publisher, Ltd.

Hew, K. F., \& Brush, T. (2007). Integrating technology into K-12 teaching and learning: current knowledge gaps and recommendations for future research. Education Technology Research \& Development, 223-252. https://doi.org/10.1007/s11423-006-9022-5

İbili, E. (2013). Development, implementation and assessment of the effect augmented reality on geometry teaching materials for geometry classes. Doctorate Thesis. Gazi University, Ankara.

İbili, E., \& Şahin, S. (2013). Software design and development of an interactive 3D geometry book using augmented reality: ARGE3D. Afyon Kocatepe University Journal of Science and Engineering, 13(1), 1-8. https://doi.org/10.5578/fmbd.6213

Kellner, D. (2002). Yeni Teknolojiler/ Yeni Okuryazarlıklar: Yeni Bin Yılda Eğitimin Yeniden Yapılandırılması. Çev. Taşkent, A. Kuram ve Uygulamada Eğitim Bilimleri, 2(1), 105-132.

Krathwohl, D. R. (2002). A revision of Bloom's taxonomy: An overview. Theory into Practice, 41(4), 212-218. https://doi.org/10.1207/s15430421tip4104_2

Lincoln, Y. S., \& Guba, E. G. (1985). Naturalistic inquiry (Vol. 75). Sage.

Milgram, P. (1994). A taxonomy of mixed reality visual displays. IEICE Transactions on Information and systems, 77(12), 1321-1329.

Milgram, P., Takemura, H., Utsumi, A., \& Kishino, F. (1994). Augmented reality: a class of displays on the reality-virtuality continuum. In Proceedings of Telemanipulator and Telepresence Technologies (SPIE), 282-292.

Münir, E. (2010). A 3D topologıcal tracking system for augmented reality. Master Thesis, Middle East Technical University, Ankara.

Neumann, U., \& Majoros, A. (1998). Cognitive, performance, and systems issues for augmented reality applications in manufacturing and maintenance. Proceedings of IEEE the Virtual Reality Annual International Symposium (VRAIS), 4-9. https://doi.org/10.1109/VRAIS.1998.658416

Newby, T. J., Stepich, D. A., Lehman, J. D., \& Russell, J. D. (1996). Instructional technology for teaching and learning. USA: Prentice-Hall, Inc.

Nunez, M., Quiros, R., Nunez, I., Carda, J. B., \& Camahort, E. (2008). Collaborative augmented reality for inorganic chemistry education. New Aspects of Engineering Education, 271-277.

Özarslan, Y. (2013). The effect of augmented reality enhanced learning materials on learners' achievement and learners' satisfaction. Doctorate Thesis, Anadolu University, Eskişehir.

Özbay, E. (2013). A kinect-based application for modelling three-dimensional objects. Master Thesis, Firat University, Elazığ.

Özer-Özkan, Y., \& Acar-Güvendir, M. (2013). Öğrencilerin ölçme ve değerlendirme dersinin sunulmasında tercih ettikleri öğretim yöntemleri. Eğitimde ve Psikolojide Ölçme ve Değerlendirme Dergisi, 4(1), 1-14.

Perey, C., \& Wrangler, S. (2011). Augmented Reality for Learning. Retrieved September 01, 2017, from http://www.perey.com/AR_for_Learning_Feb_22_2011.pdf

Resta, P., \& Laferrière, T. (2007). Technology in support of collaborative learning. Educational Psychology Review, 19(1), 65-83. https://doi.org/10.1007/s10648-007-9042-7

Robertson, I. (2008). Learners' attitudes to wiki technology in problem based, blended learning for vocational teacher education. Australian Journal of Educational Technology, 24(4), 425-441. https://doi.org/10.14742/ajet.1202

Shea, A. M. (2014). Student perceptions of a mobile augmented reality game and willingness to communicate in japanese. Doctorate Thesis. Pepperdine University, Malibu.

Somyürek, S. (2014). Gaining the attention of generation $\mathrm{z}$ in learning process: augmented reality. Education Technology Theory and Practice, 4(1), 63-80.

Somyürek, S., Atasoy, B., \& Özdemir, S. (2009). Board's IQ: What makes a board smart? Computers \& Education, 53(2), 368-374. https://doi.org/10.1016/j.compedu.2009.02.012

Squire, K. D., \& Jan, M. (2007). Mad City Mystery: Developing scientific argumentation skills with a place-based augmented reality game on handheld computers. Journal of Science Education and Technology, 16(1), 5-29. https://doi.org/10.1007/s10956-006-9037-z

Ünal, F. C. (2013). Use of augmented reality technologies in architectural guide; the evaluation on Eindhoven city. 
Master Thesis, İstanbul Technical University, İstanbul.

Van Krevelen, D. W. F., \& Poelman, R. (2010). A survey of augmented reality technologies, applications and limitations. International Journal of Virtual Reality, 9(2).

Welch, G., \& Foxlin, E. (2002). Motion tracking: No silver bullet, but a respectable arsenal. IEEE Computer Graphics and Applications, 22(6), 24-38. https://doi.org/10.1109/MCG.2002.1046626

Yeşilyurt, E. (2013). Teachers' aim in using teaching methods and problems they encounter. Journal of Atatürk University Social Science Institution, 17(1), 163-188.

Yıldırım, A., \& Şimşek, H. (2011). Sosyal bilimlerde nitel araştırma yöntemleri (5. Baskı). Ankara: Seçkin Yayınevi.

\section{Copyrights}

Copyright for this article is retained by the author(s), with first publication rights granted to the journal.

This is an open-access article distributed under the terms and conditions of the Creative Commons Attribution license which permits unrestricted use, distribution, and reproduction in any medium, provided the original work is properly cited. 